\title{
Redistributive Income Taxation, Outsourcing and Foreign Direct Investment***
}

\author{
Thomas Aronsson* and Erkki Koskela**
}

June 2010

\begin{abstract}
This paper deals with optimal income taxation under international outsourcing and FDI. We show how the joint effect of outsourcing and FDI on the optimal marginal income tax rates depends on whether FDI is horizontal or vertical.
\end{abstract}

Keywords: optimal taxation, redistribution, outsourcing, foreign direct investment.

JEL Classification: D60, H21, H23, H25, J31.

* Corresponding author. Department of Economics, Umeå University, SE - 90187 Umeå, Sweden; E-mail: Thomas.Aronsson@econ.umu.se; Phone: +46-90-7865017; fax: +46-90772302.

** Department of Economics, P.O. Box 17 (Arkadiankatu 17), 00014 University of Helsinki, Finland.

*** The authors would like to thank Tomas Sjögren for helpful comments and suggestions. Aronsson would also like to thank The Bank of Sweden Tercentenary Foundation, The Swedish Council for Working Life and Social Research, and The Swedish National Tax Board for research grants. Koskela thanks Academy of Finland (grant No. 1217622) for financial support. 


\section{Introduction}

In the process of globalization, international outsourcing and foreign direct investment (FDI) have become increasingly important aspects of production and industrial organization. International outsourcing is meant to imply that some production stages - typically low-skilled labor intensive production - is carried out by a foreign partner, whereas FDI implies that firms invest part of their capital stock abroad instead of domestically (a process that may, or may not, be directly associated with outsourcing). A large empirical literature has examined the distributional consequences of outsourcing, where the common message is that international outsourcing leads to more wage-inequality by increasing the skill-premium in countries that outsource production abroad. ${ }^{1}$ The (more scarce) literature dealing with the distributional consequences of FDI conveys a similar message. ${ }^{2}$

Yet, the literature dealing with the implications of globalization for optimal income taxation is surprisingly small. The purpose of this note is to analyze the simultaneous effects of outsourcing and FDI on the optimal use of redistributive income taxation. The analysis is based on the two-type optimal income tax model (developed in its original form by Stern 1982 and Stiglitz 1982), which is here modified to allow for outsourcing of low-skilled labor intensive production as well as FDI. Our study focuses on a country whose firms outsource production and invests part of its capital stock abroad (outward FDI). As such, the present study extends the recent paper by Aronsson and Koskela (2009), who examined the optimal income tax response to outsourcing without considering the effects of FDI. This extension is well motivated, because outsourcing and FDI jointly affect the domestic wage-distribution and, therefore, also the incentives underlying redistributive policy.

\section{The Model}

There are two types of consumers: a low-ability type $(i=1)$ and a high-ability type $(i=2)$. This distinction refers to productivity, meaning that the high-ability type is more productive and faces a higher before-tax wage rate than the low-ability type. As the number of

See, e.g., Feenstra and Hanson (1999), Hijzen (2007), Hsieh and Woo (2005) and Geishecker and Görg (2008).

2 See, e.g., Choi (2006), who finds that both inward and outward FDI leads to increased inequality measured by the GINI coefficient. 
individuals of each such type is not important, it will be normalized to one. The utility function facing ability-type $i$ is given by

$$
u^{i}=u\left(c^{i}, z^{i}\right)
$$

where $c$ is consumption and $z$ leisure. Leisure is defined as a time endowment less the hours of work, $l$. Let $w^{i}$ denote the before-tax hourly wage rate and $T\left(w^{i} l^{i}\right)$ the income tax payment faced by ability-type $i$. The individual budget constraint can then be written as

$$
w^{i} l^{i}-T\left(w^{i} l^{i}\right)-c^{i}=0 .
$$

The first order condition for work hours becomes (subindices denote partial derivatives)

$$
u_{c}^{i} w^{i}\left(1-T^{\prime}\left(w^{i} l^{i}\right)\right)-u_{z}^{i}=0
$$

where $T^{\prime}\left(w^{i} l^{i}\right)$ is the marginal income tax rate.

Turning to production, the representative firm uses four variable inputs: domestic labor of each ability-type, $l^{1}$ and $l^{2}$; outsourcing, $m$; and FDI, $I$. By slightly extending the production-model used in Koskela and Stenbacka (2010), we write the production function as follows;

$$
y=F\left(l^{1}+\delta m, I^{2}, I\right)
$$

where $y$ denotes output, while $\delta>0$ is a parameter. The variable $m$ is interpretable as an intermediate good bought from a foreign partner; alternatively, this good may be manufactured domestically by use of low-skilled labor (this process is embedded in the production function). The production function is increasing and strictly concave in each of its three separate arguments - i.e. $F_{\tilde{I}^{1}}>0, F_{l^{2}}>0, F_{I}>0$, and $F_{\tilde{I}^{1} \tilde{l}^{1}}<0, F_{l^{2} l^{2}}<0, F_{I I}<0$, where $\tilde{l}^{1}=l^{1}+\delta m$ - and the technology is characterized by constant returns to scale. We also assume that the two types of domestic labor are technical complements in the sense that $F_{\tilde{l}^{1} l^{2}}>0$. This formulation means that increased outsourcing leads to higher wage-inequality. 
Whether FDI is a technical complement or technical substitute to domestic labor is subject to debate, and we consider both these scenarios below. ${ }^{3}$ In Case I, domestic labor and FDI are technical substitutes in the sense that $F_{\tilde{l}^{1} I}<0$ and $F_{l^{2} I}<0$, whereas Case II implies that domestic labor and FDI are technical complements such at $F_{\tilde{l}^{1} I}>0$ and $F_{l^{2} I}>0 .{ }^{4}$ Case I is interpretable to reflect market-seeking (horizontal) FDI, and Case II to reflect cost-saving (vertical) FDI. In each such case, our main results will be derived under the assumption that increased FDI leads to increased domestic wage-inequality (see footnote 2). However, as the effect of FDI on the wage distribution is uncertain, we also discuss how the results are modified if increased FDI instead leads to less domestic wage-inequality.

There is also a cost associated with outsourcing, $\psi(m)$, and FDI, $q(I)$, each of which is increasing and strictly convex in its argument. The first order conditions can be written as

$$
\begin{aligned}
& F_{\tilde{I}^{1}}\left(l^{1}+\delta m, l^{2}, I\right)-w^{1}=0 \\
& F_{l^{2}}\left(l^{1}+\delta m, l^{2}, I\right)-w^{2}=0 \\
& \delta F_{I^{1}}\left(l^{1}+\delta m, l^{2}, I\right)-\psi_{m}(m)=0 \\
& F_{I}\left(l^{1}+\delta m, l^{2}, I\right)-q_{I}(I)=0
\end{aligned}
$$

where subindices denote partial derivatives. Since the decision-problem facing the government will be written in terms of $l^{1}$ and $l^{2}$, it will be convenient to solve equations (7) and (8) for $m$ and $I$, respectively, as functions of $l^{1}$ and $l^{2}$. These functions can be written as

$$
\begin{aligned}
& m=m\left(l^{1}, l^{2}\right) \\
& I=I\left(l^{1}, l^{2}\right) .
\end{aligned}
$$

3 Based on cross-country data, Feldstein (1995) and Desai et al. (2005) find that domestic investment tends to decline in response to outward FDI (in what appears to be a one-to-one relationship). If domestic labor and domestic capital are technical complements, then this would suggest that domestic labor and foreign direct investment ought to be treated as technical substitutes in the production function set out above. However, by focusing solely on U.S. multinationals, Desai et al. find the opposite relationship between domestic investment and outward FDI; namely, that increased FDI by U.S. multinationals tends to increase the domestic investment as well.

$4 \quad$ See also the overview article by Crino (2009), which suggests that domestic and foreign labor are typically substitutes in the context of multinationals. 
With the assumptions made above, one can show that equation (9a) typically implies $\partial m / \partial l^{1}<0$ and $\partial m / \partial l^{2}>0 .^{5}$ For equation (9b), the comparative statics results depend on whether FDI is complementary with, or substitutable for, domestic labor. If domestic labor and FDI are technical substitutes (Case I), we have $\partial I / \partial l^{1}<0$ and $\partial I / \partial l^{2}<0$; if they are technical complements (Case II), we obtain $\partial I / \partial l^{1}>0$ and $\partial I / \partial l^{2}>0$.

\section{Optimal Income Taxation}

We analyze Pareto efficient taxation by assuming that the government maximizes the utility of the low-ability type subject to a minimum utility restriction for the high-ability type. The minimum utility restriction for the high-ability type is given by (for minimum utility $\bar{u}^{2}$ )

$$
u^{2}=u\left(c^{2}, z^{2}\right) \geq \bar{u}^{2}
$$

The informational assumptions are conventional. The government knows the income of each individual, while ability is private information. By following much earlier literature in assuming that redistribution means income transfers from the high-ability to the low-ability type, one would like to prevent the high-ability type from becoming a mimicker. The selfselection constraint that may bind then becomes

$$
u^{2}=u\left(c^{2}, z^{2}\right) \geq u\left(c^{1}, H-\phi l^{1}\right)=\hat{u}^{2}
$$

where $\hat{u}^{2}$ denotes the utility of the mimicker, and $\phi=w^{1} / w^{2}<1$ is the relative wage rate. The mimicker faces the same income and consumption point (and, therefore, pays as much tax as) the low-ability type. As the mimicker is more productive than the low-ability type, he/she spends more time on leisure. By using the first order conditions for the firm, one can write $\phi$ as a function of $l^{1}, l^{2}, m$ and $I$, i.e.

5 Strictly speaking, a linear outsourcing cost, $\psi_{m m}(m)=0$, is sufficient - yet not necessary - to ensure that $\partial m / \partial l^{1}<0$. If $\psi_{m m}(m)>0$ (as we assume here), and if $\tilde{l}^{1}=l^{1}+\delta m$ and $I$ are either strong enough substitutes or strong enough complements, we can no longer rule out the possibility that $\partial m / \partial l^{1}>0$. To focus on basic intuition, we will not discuss this somewhat unlikely scenario here. 


$$
\phi=\phi\left(l^{1}, l^{2}, m, I\right)
$$

With equation (4) at our disposal, it is straight forward to show that $\partial \phi / \partial m<0$. As empirical evidence also suggests that outward FDI contributes to increased inequality, which is here interpreted to mean $\partial \phi / \partial I<0$, this implies additional (implicit) restrictions on the production function. To be more specific, for $\partial \phi / \partial I<0$ to hold, Case I implies $F_{\tilde{I}^{1} I} / F_{l^{2} I}>\phi$ which is always fulfilled if FDI is at least as substitutable for low-skilled labor as it is for high-skilled labor; in Case II, the corresponding condition is given by $F_{\tilde{I}^{1} I} / F_{I^{2} I}<\phi$ which presupposes that FDI is a stronger complement to high-skilled than to low-skilled labor.

By using $\sum_{i} T\left(w^{i} l^{i}\right)=0$ together with the private budget constraints and the objective function of the firm, we can write the budget constraint faced by government as follows;

$$
F\left(l^{1}+\delta m, l^{2}, I\right)-\sum_{i} c^{i}-\psi(m)-q(I)=0
$$

The Lagrangean is given by

$$
L=u^{1}+\rho u^{2}+\lambda\left[u^{2}-\hat{u}^{2}\right]+\gamma\left[F\left(l^{1}+\delta m, I^{2}, I\right)-\sum_{i} c^{i}-\psi(m)-q(I)\right]
$$

where $\rho, \lambda$ and $\gamma$ are Lagrange multipliers. To shorten the notation, let $\Delta_{m}$ and $\Delta_{I}$ denote the welfare effect following an increase in outsourcing and FDI, respectively. By using the first order conditions of the firm and the assumptions underlying the wage-distribution, we have

$$
\begin{aligned}
& \Delta_{m}=\frac{\partial L}{\partial m}=\lambda \hat{u}_{z}^{2} l^{1} \frac{\partial \phi}{\partial m}<0 \\
& \Delta_{I}=\frac{\partial L}{\partial I}=\lambda \hat{u}_{z}^{2} I^{1} \frac{\partial \phi}{\partial I}<0 .
\end{aligned}
$$

The government's first order conditions for hours of work and consumption can be written as 


$$
\begin{aligned}
& -u_{z}^{1}+\lambda \hat{u}_{z}^{2}\left[\phi+l^{1} \frac{\partial \phi}{\partial l^{1}}\right]+\gamma w^{1}+\Delta_{m} \frac{\partial m}{\partial l^{1}}+\Delta_{I} \frac{\partial I}{\partial l^{1}}=0 \\
& u_{c}^{1}-\lambda \hat{u}_{c}^{2}-\gamma=0 \\
& -(\delta+\lambda) u_{z}^{2}+\lambda \hat{u}_{z}^{2} l^{1} \frac{\partial \phi}{\partial l^{2}}+\gamma w^{2}+\Delta_{m} \frac{\partial m}{\partial l^{1}}+\Delta_{I} \frac{\partial I}{\partial l^{1}}=0 \\
& (\delta+\lambda) u_{c}^{2}-\gamma=0 .
\end{aligned}
$$

The marginal income tax rate implemented for the low-ability type can be derived by combining equations (3), (15) and (16), and for the high-ability type by combining equations (3), (17) and (18). Let $M R S_{z, c}^{i}$ and $M \hat{R} S_{z, c}^{2}$ denote the marginal rate of substitution between leisure and private consumption for ability-type $i$ and the mimicker, respectively. We can then derive the following expressions for the marginal income tax rates;

$$
\begin{aligned}
& T^{\prime}\left(w^{1} l^{1}\right)=\frac{\lambda^{*}}{w^{1}}\left[M R S_{z, c}^{1}-\phi M \hat{R} S_{z, c}^{2}\right]-\frac{\lambda}{\gamma w^{1}} \hat{u}_{z}^{2} I^{1} \frac{\partial \phi}{\partial l^{1}}-\Delta_{m} \frac{\partial m}{\partial l^{1}}-\Delta_{I} \frac{\partial I}{\partial l^{1}} \\
& T^{\prime}\left(w^{2} l^{2}\right)=-\frac{\lambda}{\gamma w^{2}} \hat{u}_{z}^{2} I^{1} \frac{\partial \phi}{\partial l^{2}}-\Delta_{m} \frac{\partial m}{\partial l^{2}}-\Delta_{I} \frac{\partial I}{\partial l^{2}}
\end{aligned}
$$

where $\lambda^{*}=\lambda \hat{u}_{c}^{2} / \gamma$. In the absence of outsourcing and FDI, i.e. if $\Delta_{m}=\Delta_{I}=0$, equations (19) and (20) would coincide with the marginal income tax rate formulas derived by Stiglitz (1982).

The terms proportional to $\Delta_{m}$ and $\Delta_{I}$ are due to the appearance of outsourcing and FDI, respectively. Note that both these components are, in turn, proportional to the Lagrange multiplier associated with the self-selection constraint, meaning that the policy incentives created by outsourcing and FDI are due to the desire to relax the self-selection constraint. Since $\Delta_{m}<0, \partial m / \partial l^{1}<0$ and $\partial m / \partial l^{2}>0$, it follows that outsourcing by itself contributes to decrease the marginal income tax rate implemented for the low-ability type and increase the marginal income tax rate implemented for the high-ability type. Aronsson and Koskela (2009) derived an analogous result in a model without FDI. We also see that the appearance of FDI contributes to decrease both marginal income tax rates in Case I and increase both marginal income tax rates in Case II. 
We have derived the following results with respect to the joint effect of outsourcing and FDI on the marginal income tax rates;

Proposition 1. Case I. If FDI is substitutable for domestic labor, then the joint effect of outsourcing and FDI is to decrease the marginal income tax rate implemented for the lowability type, whereas the marginal income tax rate implemented for the high-ability type may change in either direction.

Case II. If FDI is complementary with domestic labor, then the joint effect of outsourcing and FDI is to increase the marginal income tax rate implemented for the high-ability type, whereas the marginal income tax rate faced by the low-ability type may change in either direction.

These policy-responses reflect an incentive to simultaneously reduce the levels of outsourcing and FDI which, in turn, means reduced wage-inequality. In Case I, where FDI is horizontal, this can be accomplished via increased hours of work supplied by the low-ability type; therefore, the optimal policy-response is to decrease the marginal income tax rate implemented for the low-ability type. The corresponding marginal tax rate response for the high-ability type depends on whether the incentive to reduce the level of outsourcing via a smaller labor supply dominates or is dominated by the incentive to reduce the FDI via increased labor supply by the high-ability type. In Case II, where FDI is vertical, we may simultaneously reduce the levels of outsourcing and FDI by implementing a higher marginal income tax rate for the high-ability type, whereas the corresponding change in the marginal income tax rate of the low-ability type reflects two counteracting incentives.

Note finally that if increased FDI instead leads to less wage-inequality, the results presented in Proposition 1 must be modified, as the government in this case may reduce the wage-inequality by implementing policies that lead to increased in FDI. In Case I, we find that the government implements a higher marginal income tax rate for the high-ability than it would have done in the absence of outsourcing and FDI, whereas the change in the marginal income tax rate implemented for the low-ability type is ambiguous. In Case II, the optimal policy-response means a lower marginal income tax rate of the low-ability type, while the joint effect of outsourcing and FDI on the marginal income tax rate of the high-ability type is ambiguous. 


\section{References}

Aronsson, T. and Koskela, E. (2009) Outsourcing and Optimal Nonlinear Taxation: A Note. Economics Letters 102, 135-137.

Choi, C. (2006) Does Foreign Direct Investment Affect Domestic Income Inequality? Applied Economics Letters 13, 811-814.

Crino, R. (2009) Offshoring, Multinationals and Labor Market: A Review of the Empirical Literature. Journal of Economic Surveys 23, 197-249.

Desai, M. C., Foley, C. F. and Hines Jr, J. R. (2005) Foreign Direct Investment and the Domestic Capital Stock. American Economic Review 95, 33-38.

Feenstra, R.C. and Hanson, G.H. (1999) The Impact of Outsourcing and High-Technology Capital on Wages. Quarterly Journal of Economics 114, 907-940.

Feldstein, M. (1995) The Effects of Outbound Foreign Direct Investment on the Domestic Capital Stock. In Feldstein, M., Hines Jr, J. R. and Hubbard, G. J. (Eds) The Effects of Taxation on Multinational Corporations. University of Chicago Press, 43-66.

Geishecker, I. and Görg, H. (2008) Winners and Losers: A Micro-Level Analysis of International Outsourcing and Wages. Canadian Journal of Economics 41, 243-270.

Hijzen, A. (2007) International Outsourcing, Technological Change, and Wage Inequality. Review of International Economics 15, 188-205.

Hsieh, C-T. and Woo, K.T. (2005) The Impact of Outsourcing to China on Hong Kong's Labor Market. American Economic Review 95, 1673-1687.

Koskela, E. and Stenbacka, R. (2010) Equilibrium Unemployment with Outsourcing and Wage Solidarity under Labor Market Imperfections. European Economic Review 54, 376-392.

Stern, N.H. (1982) Optimum Taxation with Errors in Administration. Journal of Public Economics 17, 181-211.

Stiglitz, J. E. (1982) Self-Selection and Pareto Efficient Taxation. Journal of Public Economics 17, 213-240. 